\title{
Livelihood gains and ecological costs of non-timber forest product dependence: assessing the roles of dependence, ecological knowledge and market structure in three contrasting human and ecological settings in south India
}

\author{
R. UMA SHAANKER ${ }^{1,2,3 *}$, K.N. GANESHAIAH ${ }^{1,3,4}$, SMITHA KRISHNAN $^{1}$, R. RAMYA $^{1}$, \\ C. MEERA ${ }^{1}$, N.A. ARAVIND ${ }^{1}$, ARVIND KUMAR ${ }^{1}, \operatorname{DINESH~RAO}^{1}, \mathrm{G}^{\mathrm{V}} \mathrm{VANARAJ}^{1}$, \\ J. RAMACHANDRA ${ }^{1}$, REMI GAUTHIER ${ }^{5}$, JABOURY GHAZOUL ${ }^{6}$, NIGEL POOLE \\ AND B.V. CHINNAPPA REDDY \\ ${ }^{1}$ Ashoka Trust for Research in Ecology and the Environment, \#659, 5th A Main, Hebbal, Bangalore 560024, India, ${ }^{2}$ Department of Crop \\ Physiology, University of Agricultural Sciences, GKVK Campus, Bangalore 560065, India, ${ }^{3}$ Famaharlal Nehru Centre for Advanced Scientific \\ Research, Fakkur, Bangalore 560 065, India, ${ }^{4}$ Department of Genetics and Plant Breeding, University of Agricultural Sciences, GKVK Campus, \\ Bangalore 560065, India, ${ }^{5}$ Imperial College London, Wye Campus, Wye, Ashford, Kent, United Kingdom, ${ }^{6}$ Imperial College London, Silmood \\ Park Campus, Ascot, Berks, United Kingdom and ${ }^{7}$ Department of Agricultural Economics, University of Agricultural Sciences, GKVK Campus, \\ Bangalore 560065, India
}

Date submitted: 23 July 2003 Date accepted: 9 September 2004

\section{SUMMARY}

Non-timber forest products (NTFPs) constitute the single largest determinant of livelihoods for scores of forest fringe communities and poor people in the tropics. In India over 50 million people are believed to be directly dependent upon NTFPs for their subsistence. However, such human dependence on NTFPs for livelihood gains (win) has most frequently been at a certain ecological cost (lose). If livelihoods are to be maintained, the existing 'win-lose' settings have to be steered to a 'win-win' mode, otherwise, there could be severe erosion of the biological resources and loss of livelihoods ('lose-lose'). Examining the dependence of forest fringe communities on NTFPs at three sites in south India with contrasting human and ecological settings, three key factors (extent of dependence on NTFPs, indigenous ecological knowledge and market organization) are likely to constrain reaching the win-win situation. How these factors shape the ecological cost of harvesting NTFPs at the three sites is examined. Within the parameter space of these factors, it is possible to predict outcomes and associations that will conform to win-win or winlose situations. Empirical data derived from the three study sites demonstrate the causality of the observed associations. The key for long-term livelihood gains lies in reducing the ecological cost. Certain interventions and recommendations that could optimize the balance between livelihood gains and ecological cost are proposed.

\footnotetext{
* Correspondence: Dr R. Uma Shaanker Tel: +91 8023636350 Fax: +91 8023530070 e-mail: rus@vsnl.com
}

Keymords: ecological costs, ecological knowledge, livelihood gains, non-timber forest product, NTFP, Western Ghats, win-win situation

\section{INTRODUCTION}

Non-timber forest products (NTFPs) constitute an important source of livelihood for millions of people from forest fringe communities across the world. In India alone, it is estimated that over 50 million people are dependent on NTFPs for their subsistence and cash income (National Centre for Human Settlements and Environment 1987; Hegde et al. 1996). NTFPs also serve as a vital livelihood safety net in times of hardship. Furthermore, the NTFP extraction has multiplier effects in the economy by generating employment and income in downstream processing and trading activities (Nepstad et al. 1992). An important feature of the dependence is that almost all NTFPs are harvested from natural forest populations. Thus, NTFPs are often deemed to have public good characteristics, with no explicit property rights (Hall \& Bawa 1993). Consequently, extraction is often intense and exhaustive because of lack of alternative income sources, unreliable productivity and the pressure to maximize shortterm income. In recent years with the advent of globalization, there are indications of a rapid increase in the extraction mostly from natural populations (R. Uma Shaanker, unpublished data 2004).

\section{Ecological costs of NTFP dependence}

The livelihood gains from NTFPs to forest communities, however, are not without ecological cost, ranging from decline of the resources (Tewari 1993; Nepstad et al. 1992; Uma Shaanker et al. 2000, 2001; Padmini et al. 2001), to changes in the population dynamics and demography of harvested 
species (Sinha \& Bawa 2001). In the southern Western Ghats in India, Chaluvaraju et al. (2001) reported a monotonic decrease in the extraction volumes of bamboo, presumably as a consequence of over extraction of these resources. Associated with the decrease, there has been an increased use of bamboo substitutes in pulp industries in the state (Chaluvaraju et al. 2001). In southern India, presumably because of extraction pressures, as many as 110 species of medicinal plants are reported to have become rare, endangered and threatened (Ved et al. 2001).

Besides the direct costs, extraction of NTFPs entails a number of indirect costs. Extraction of NTFPs has impact at the levels of the genes (Padmini et al. 2001), community (Ganeshaiah et al. 1998) and the ecosystem (Uma Shaanker et al. 2001; Bawa et al. 2002), such as in disrupting ecosystem services (for example pollinator services; Ghazoul 2001). There could be also a 'knowledge' cost consequent upon the loss of resources. In southern India, loss of bamboo has led to an erosion of the knowledge and skills associated with the working of bamboo in communities that have been traditionally dependent on bamboo (Chaluvaraju et al. 2001).

While a number of studies have documented the role of NTFPs in livelihoods (Hegde et al. 1996; Murali et al. 1996; Ganeshaiah et al. 1998; Peres et al. 2003), few have critically analysed the conflict between livelihood gains and ecological costs and how the long-term livelihoods could be safeguarded.

In this paper, we focus on the balance between securing long-term livelihoods and the associated ecological costs of forest use. Crucial to the latter is to understand the factors that influence the ecology of the harvested species as well as the ecosystem at large. Among other factors, we examine in this paper the roles played by three, namely the extent of dependence, indigenous ecological knowledge and the market structure in influencing the ecological cost in three contrasting settings in south India. Based on the study, we propose interventions that could help lower the ecological cost and maintain or enhance existing livelihoods.

Among other factors, the use of forest resources for livelihood gains could feed into ecological costs, primarily as a function of (1) extent of dependence, (2) indigenous ecological knowledge and (3) market organization and the institutional framework (Fig. 1).

The terms 'institution/s' and 'institutional framework' are used here in the New Institutional Economics sense of the formal laws and the informal norms of conduct that shape the (economic) incentives and regulate commercial behaviour (see, for example, North 1990). These include property rights, buyer-seller contracts and auction mechanisms. 'Organization' and 'organizations' refer to the economic 'players' or 'market agents', individuals, associations such as cooperatives and private firms who undertake commercial transactions in goods and services, and their buyer-seller relationships, governed by the institutional framework and legal enforcement mechanisms.

Within the common property rights literature, Ostrom (1990, p. 2) ascribes importance to the role of voluntary

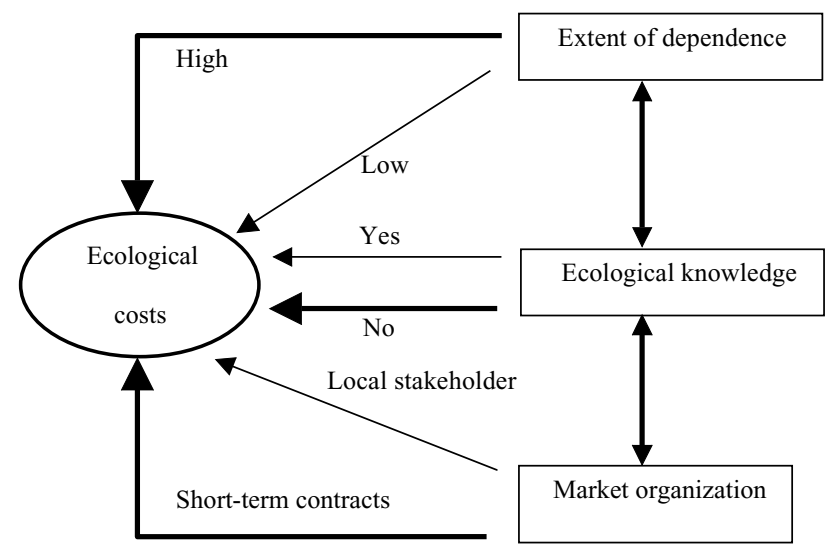

Figure 1 Diagram illustrating the influence of dependence, ecological knowledge and market organization and institutions on the ecological cost of forest use. The thickness of the arrows indicates relative cost (bold $=$ higher cost and pale $=$ lower cost) .

organizations in overcoming the 'tragedy of the commons', defined as 'the degradation of the environment to be expected whenever many individuals use a scarce resource in common' as an alternative to privatization or state control.

High dependence, low or no ecological knowledge and an exploitative market (say through short-term private contractors, in contrast to marketing by forest-margin dweller stakeholders) are likely to impose high ecological costs (Fig. 1). When dependence on forest products is low, independent of the ecological knowledge status of the people as well as the market structure, the ecological costs are bound to be low. However when dependence is high, as is the case most often in countries such as India, the ecological costs will be primarily determined by the status of knowledge among the people and the market structure and institutions. In general, it could be hypothesized that high dependence coupled with a low knowledge status and a high degree of institutional failure could have a high ecological cost. Alternatively, high dependence, if associated with a good knowledge status, as well as a long-term incentive structure with secure property rights and local stakeholder marketing, is likely to lead to a milder ecological cost.

The weighting of the arrows in Figure 1 is indicative of the likely effects among the variables. Thus, the extent of dependence could influence the ecological knowledge of the people as much as the knowledge might influence extent of dependence. Market systems, such as collectors' cooperatives might extend knowledge amongst collectors more than if marketing were effected through short-term private contracts. However, it is not unlikely that possession of ecological knowledge could influence how a product is going to be marketed. The relative strengths of these linkages might be important in determining the final payoffs into the gains and costs. Accordingly, and based on the above hypothesis, two specific predictions or associations follow: (1) sites or communities with higher dependence on forest resources but with a good ecological knowledge will tend to impose 
a lesser ecological cost compared with those that exhibit a poor ecological knowledge; and (2) sites with a cooperative stakeholder-marketing regime will impose a lower ecological cost than would those where marketing is conducted through private traders operating under short-term contracts.

Thus the ecological cost of forest use could be driven by the extent of dependence, by the indigenous ecological knowledge of the harvesting communities, and the market organization and institutions. Several additional factors could also influence the cost, such as the proximity to market and market demand conditions. We briefly explore these possibilities. Below we derive empirical data from three contrasting settlements in south India and discuss the causality of the observed associations and strategies to lower the ecological cost while maintaining the livelihoods.

\section{MATERIALS AND METHODS}

\section{Study sites}

The study was conducted at three sites in south India, namely Malai Mahadeshwara Hills (MM Hills), Biligiri Rangaswamy Temple Wildlife sanctuary (BR Hills) and Rajiv Gandhi National Park (Nagarahole), all in Karnataka, south India (Fig. 2). These sites provide contrasting human and ecological settings (Table 1).

Of the three, MM Hills is a reserve forest, while the other two are protected areas. The latter are protected by legislation against human activities, including harvesting of NTFPs and grazing. However, because of historical contingencies, at the two protected areas chosen for the study people continue to extract NTFPs.

At BR Hills, an endogamous tribe, the Soligas reside within the sanctuary and live off the NTFP resources in the forest (Ganeshaiah \& Uma Shaanker 1998). The Karnataka State

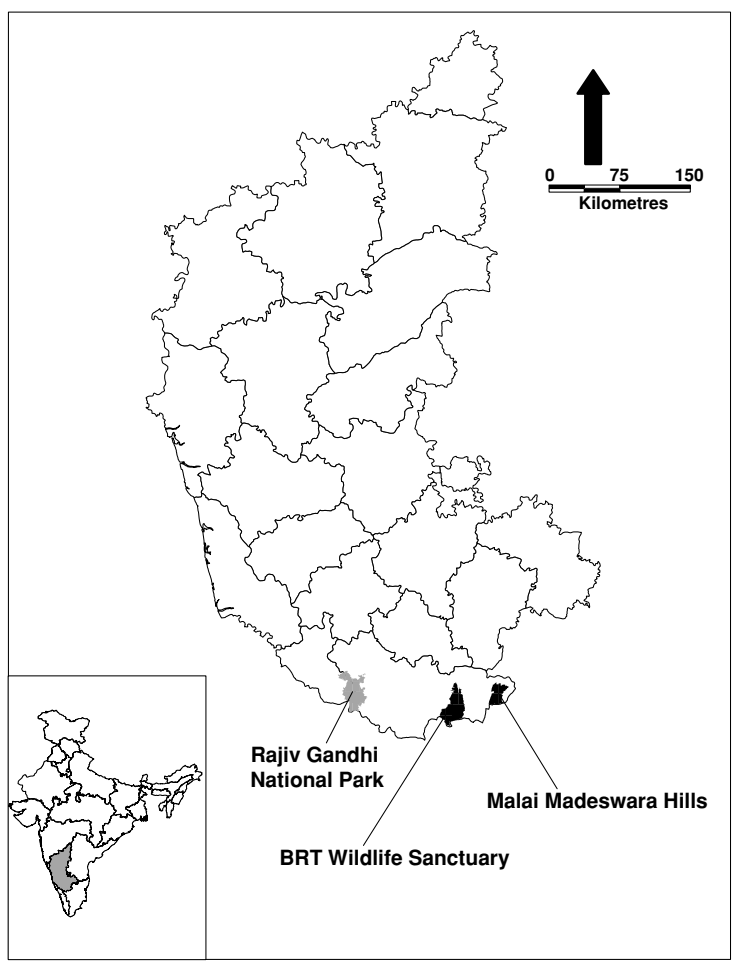

Figure 2 Map showing the three study sites in south India.

Forest Department allows the people informal rights to collect NTFPs and market them through a local cooperative, the Large-scale Adivasi Multi-purpose Society (LAMPs; Murali et al. 1996). At Nagarahole, which was recently declared a national park, the forest dwelling communities, the Kurubas and fenu Kurubas, are now denied forest rights, and have been moved out and rehabilitated in the forest fringes; however,

Table 1 Features of the three sites selected for the study. *For further details, see text.

\begin{tabular}{|c|c|c|c|}
\hline Characteristics & MM Hills & BR Hills & Nagarahole \\
\hline Legal status & Reserve forest & Wildlife sanctuary (protected area) & National park (protected area) \\
\hline Location & $\begin{array}{c}11^{\circ} 56^{\prime}-12^{\circ} 09^{\prime} \mathrm{N} \text { and } \\
77^{\circ} 30^{\prime}-77^{\circ} 42^{\prime} \mathrm{E}\end{array}$ & $\begin{array}{l}11^{\circ} 40^{\prime}-12^{\circ} 09^{\prime} \mathrm{N} \text { and } \\
77^{\circ} 05^{\prime}-77^{\circ} 15^{\prime} \mathrm{E}\end{array}$ & $\begin{array}{l}11^{\circ} 45^{\prime}-12^{\circ} 15^{\prime} \mathrm{N} \text { and } \\
76^{\circ} 05^{\prime}-76^{\circ} 25^{\prime} \mathrm{E}\end{array}$ \\
\hline Area $\left(\mathrm{km}^{2}\right)$ & 291 & 540 & 643 \\
\hline Population & 5614 (1991 census data) & 4000 (interior) +11000 (periphery) & Approx. 3000 \\
\hline Altitude in $(\mathrm{m})$ & $300-1514$ & $600-1800$ & $700-959$ \\
\hline Temperature $\left({ }^{\circ} \mathrm{C}\right)$ & $\begin{array}{l}\text { Minimum } 10^{\circ} \mathrm{C} \text { and } \\
\text { maximum } 35-40^{\circ} \mathrm{C}\end{array}$ & Minimum $8^{\circ} \mathrm{C}$ and maximum $42^{\circ} \mathrm{C}$ & $\begin{array}{l}\text { Minimum } 10^{\circ} \mathrm{C} \text { and } \\
\text { maximum } 35^{\circ} \mathrm{C}\end{array}$ \\
\hline Rainfall $\left(\mathrm{mm} \mathrm{yr}^{-1}\right)$ & $400-600$ & $600-3000$ & $1300-1800$ \\
\hline Human population & $\begin{array}{l}\text { Soligas (tribal) and } \\
\quad \text { Lingayat (non-tribal) }\end{array}$ & $\begin{array}{l}\text { Soligas (tribal) and Naiks } \\
\quad \text { (non-tribal, in the periphery) }\end{array}$ & $\begin{array}{l}\text { Fenu Kurubas, Betta Kurubas } \\
\quad \text { and Yeravas (tribal) }\end{array}$ \\
\hline Tribal (\%) & $\begin{array}{l}\text { 13\% (Kombudikki) } \\
\text { 17\% (Ponnachi) }\end{array}$ & $100 \%$ & $100 \%$ \\
\hline Land tenure* & Present & Absent & Absent \\
\hline Collection of NTFPs & Permitted & Permitted* & Partially allowed* \\
\hline Main source of income & $\begin{array}{l}\text { Daily wage labour, agriculture } \\
\text { and NTFPs }\end{array}$ & NTFPs and daily wage labour & $\begin{array}{l}\text { Daily wage labour NTFPs } \\
\text { and agriculture }\end{array}$ \\
\hline Market regime & Private contractors & Tribal cooperatives & Cooperatives \\
\hline
\end{tabular}


Table 2 List, parts used and quantity of NTFPs collected in the three study sites.

\begin{tabular}{|c|c|c|c|c|c|c|}
\hline \multirow[t]{2}{*}{ NTFP resource } & \multirow[t]{2}{*}{ Scientific name } & \multirow[t]{2}{*}{ Parts used } & \multicolumn{3}{|c|}{ Total quantity (kg collector $\left.{ }^{-1} \mathrm{yr}^{-1}\right)$} & \multirow[t]{2}{*}{ Mean } \\
\hline & & & MM Hills & BR Hills & Nagarahole & \\
\hline Antuvala (soap nut) & Sapindus laurifolius & Fruits & 5136 & 2673 & 120 & 2643 \\
\hline Arale & Terminalia bellerica & Fruits & 7848 & 3728 & 0 & 3859 \\
\hline Bamboo poles & $\begin{array}{l}\text { Bambusa sp. and } \\
\text { Dendrocalamus sp. }\end{array}$ & Stems & 4220 & 0 & 0 & 1407 \\
\hline Bamboo shoots & $\begin{array}{l}\text { Bambusa sp. and } \\
\text { Dendrocalamus sp. }\end{array}$ & Shoots & 0 & 0 & 40 & 13 \\
\hline Bel & Agele marmelos & Fruits & 0 & 650 & 0 & 217 \\
\hline Koodu (horn) & Spotted deer and sambar deer & Antlers & 0 & 230 & 0 & 77 \\
\hline Dhoopa & Botswelli serrata & Resin & 0 & 2.5 & 0 & 1 \\
\hline Fuelwood & Trees and shrubs of any species & Stems and branches & 0 & 1423 & 52 & 492 \\
\hline Genasu & Dioscoria sp. & Tubers & 0 & 0 & 7866 & 2622 \\
\hline Jaenu (honey) & $\begin{array}{l}\text { Apis dorsata, A. floria and } \\
\text { Serana indica }\end{array}$ & Honey & 32 & 6226 & 7560 & 4606 \\
\hline Honge & Pongamia pinnata & Seeds & 118 & 0 & 0 & 39 \\
\hline Honne & Pterocarpus marsupium & Fruits & 126 & 0 & 0 & 42 \\
\hline Kal paase & Lichen $\mathrm{sp}$. & Thallus & 0 & 13138 & 703 & 4614 \\
\hline Kasahullu & Phoenix sp. & Leaves & 69278 & 53829 & 0 & 41036 \\
\hline Magali & Decalepis hamiltonii & Roots & 1655 & 17512 & 0 & 6389 \\
\hline Maavu (mango) & Mangifera indica & Fruits & 0 & 125 & 0 & 42 \\
\hline Nelli & $\begin{array}{l}\text { Phyllanthus emblica and } \\
\text { P. indofischeri }\end{array}$ & Fruits & 21600 & 58162 & 3100 & 27621 \\
\hline Seege & Acacia concinna & Fruits & 8242 & 525 & 0 & 2922 \\
\hline Hunase (tamarind) & Tamarindus indicus & Fruits & 4050 & 4170 & 0 & 2740 \\
\hline Anntu (wax) & $\begin{array}{l}\text { Apis dorsata, A. floria and } \\
\text { Serana indica }\end{array}$ & Honey comb & 0 & 522 & 1129 & 551 \\
\hline Taare & Terminalia chebula & Fruits & 7848 & 3728 & 0 & 3858 \\
\hline
\end{tabular}

the people continue to depend on NTFPs. They collect mostly from the periphery and buffer zones of the Park. The market organization for the NTFPs involves various channels, including both LAMPs and private traders. In MM Hills, tribal (Soligas) and non-tribal (Lingayats) people collect forest products. Unlike the other two sites, marketing is conducted through private contractors who bid for the short-term (two year) rights to various timber and non-timber products; in this process, the contractor is free to also employ collectors from within or outside the forest dwelling communities.

Thus, none of the communities has ownership rights to forest land or products, and usufructuary rights vary. At BR Hills, the Soligas do not have land-tenure, whereas at MM Hills and Nagarahole, people have tenurial rights over agricultural land within the forest jurisdiction.

A range of forest products is collected at the three sites (Table 2). All three sites are located in the eastern fringe of the Western Ghats, with similar agro-ecological conditions and similar vegetation. A number of NTFPs are common to the sites; commercialization of the NTFPs has grown significantly in the last 15-20 years in response to increasing market demand, increasing needs for cash incomes for harvesters and a shift in the dominant paradigm of the Karnataka State Forest Department from 'conservation' towards sustaining the livelihoods of forest margin dwellers (Karnataka Forest Department, unpublished data 2003). All the three sites are nearly equidistant from the major markets in south India. Very frequently the produce from the three sites is delivered to common traders in the markets of Mysore, Coimbatore and Salem in south India. Ease of vehicular access to the villages is comparable across all the three sites.

\section{Data collection and analysis}

\section{Livelihood dependence}

We adopted a stratified random sampling approach, the first stratum being the management regime (reserved forest and protected area) and the second being the community (tribals and non-tribals); within each of these, random samples were taken. The livelihood status of the people at MM Hills, BR Hills and Nagarahole was studied between April and September 2001. At all three sites, approximately $10 \%$ of the total number of households was surveyed. At MM Hills, data were obtained from two settlements, namely Kombudikki and Ponnachi. At BR Hills, the households included those from the interior and exterior limits of the Sanctuary. In Nagarahole, data were collected from people relocated to the forest fringes. The total numbers of respondents in these sites were: MM Hills 126 (Kombudikki 36, Ponnachi 90), BR Hills 53 and Nagarahole 28 households.

Data on the following livelihood variables were obtained from each of the respondents through formal interviews: size 
of the family, gender ratio, number of dependants, level of education, area of land owned and cultivated and number of livestock owned, income from various sources, number of days spent for each source of income, household expenditure and the NTFPs collected (yield and number of days spent for each).

The data were analysed by developing appropriate socioeconomic indicators as described below.

We identified the portfolio of livelihood activities for the various sites using the questionnaire method. For each component (for example agriculture or daily wage) the income contributed to the total cash income was calculated. For instance, to estimate the income obtained from collection of Phyllanthus emblica, a forest fruit, the total quantity of fruits harvested by a household per year was multiplied by the mean unit sale price of the fruits (derived from that year). The proportion of income contributed to each household by the fruits to the total income was then arrived at.

We estimated the relative contribution of different sources of cash income such as agriculture, daily wage, forest products and forest fruits to the total household income for the three sites by performing a multiple linear regression using the Statistica software package.

We computed a wealth index (WI) to determine the relationship between the total assets possessed by a household and the proportion of the total income from NTFPs. The assets included area of land owned, number of livestock owned, type of house, access to electricity, farm equipment and bank account. All the components were equally weighted. These variables were normalized (all the values were expressed in $0-1$ scale) and the mean index per household was calculated and regressed against the proportion of income contributed by NTFP to the total household income. The WI gives an indication of economic status of the community.

The Lorenz Curve (LC) was used as a graphical representation of inequality of income, assets or other type of distributions (Lorenz 1905). The graph provides a relationship between the percentage of households and the percentage of income distributed among the households. The LC was used to calculate the Gini coefficient (GC) ratio, which is the area between the line of perfect equality and the LC, and is a commonly used measure of the inequality in the distribution of income. The GC was computed following Kakwani and Podder (1976), the value of which ranges from 0 (denoting perfectly equal distribution) to 1 (denoting extreme inequality). We computed the GC for the sites to evaluate the extent to which the contribution of income from NTFPs is an important feature in reducing the income inequalities among people at each site.

\section{Ecological knomledge}

The ecological knowledge of the people was assessed in MM Hills (Sept-Dec 2000), BR Hills (April-June 2001) and Nagarahole (July-Sept 2001). The study was conducted in Ponnachi (MM Hills) with a sample of 90 households, at BR Hills with 52 households and 28 households in Nagarahole.
The households interviewed were the same as those used for the socio-economic survey. The aim of the survey was to ascertain the indigenous ecological knowledge of specific forest fruit trees that were extracted, such as Phyllanthus emblica, P. indofischeri, Terminalia chebula and Acacia concinna, and changes in general forest conditions. Information was sought on the spatial distribution of NTFP trees, methods of harvesting employed, changes in the fruit productivity with time, regeneration status of NTFP species and other trees, the influence of epiphytic parasites on trees, pollination and dispersal modes of the NTFP species, and the effect of fire and weeds on regeneration of the species.

We calculated the percentage of the respondents for each site that expressed knowledge of each of the above issues. Respondents who had no idea of an issue were regarded as not possessing knowledge on the specific ecological feature. For responses where some knowledge was expressed, the answers were categorised as unambiguously as possible into discrete categories, keeping the ecological relevance in mind. The frequency responses were evaluated using a contingency 'G' test (Sokal \& Rohlf 1981).

\section{Market structure and price spreads}

We obtained information on the market organization for NTFPs, with specific reference to forest fruits (Phyllanthus emblica, Terminalia chebula and Acacia concinna), for MM Hills and BR Hills. Depending upon the nature of distribution of respondents over a geographical area and the reliability of data generated, different sampling methods were used including simple random, stratified and clustered sampling. We used prepared schedules (after pre-testing them for their relevance) at several places and at several stages.

The data collected were analysed to trace the market chain from collector to final processor and develop commodity flow charts through which the forest fruits were marketed at BR Hills and MM Hills. From the flow charts, the main agencies involved in marketing the forest fruits were identified.

The survey was conducted by personally interviewing the major marketing agencies involved in marketing forest fruits, namely, the contractors, processors and traders. The markets surveyed include those at Kaudalli, Mysore, Bangalore, Tumkur (in Karnataka State), Salem, Erode, Coimbatore (in Tamil Nadu State), Union Territory of Pondicherry, Tuticorin and Kottekal (in Kerala State). The path that the forest products take from the collector to consumer was traced at BR Hills and MM Hills. The price of each of the commodities was also recorded at every step of the market.

To assess the price spread, the consumer prices of each of the final products were deconstructed into various cost components according to the commodity flow from source to consumers. Each margin was computed as follows:

$$
\begin{aligned}
\text { Margin }= & {[\text { (selling price of the commodity }) } \\
& -(\text { the procurement price })-(\text { the overhead cost })] \\
& \div(\text { value addition })
\end{aligned}
$$


The percentage share of the various marketing agencies in the consumer rupee was calculated for each commodity using the following function:

$$
\text { Share }=\frac{\text { Net margin or return to agent }}{\text { Consumer price of the product }} \times 100
$$

The collector's share in consumer's rupee was taken as a proxy for the percentage returns to the collectors in the total value added to the NTFP.

In some instances data limitations typical of developing country markets meant that the exact information on the goods flow, quantity, price and value addition were not available. The problem was compounded by either lack of record maintenance or inaccessibility of accounts pertaining to production, processing and transactions. Hence, two assumptions were made in computing the price spread. First, the processor's margin was assumed to be $35 \%$ of the market price, since the processor took the maximum risk of capital and technological investment. Second, the retailer's margin was considered as $10 \%$ of the market price. These assumptions are consistent with fresh produce margin studies in Delhi and Varanasi (Poole \& Bhupal 2003; Poole \& Sen 2003).

\section{Vegetation analysis}

Vegetation structure was analysed at MM Hills and Nagarahole. Vegetation was sampled along transects of $1200 \mathrm{~m}$ radiating from the settlement (in MM Hills from two sites, Kombudikki and Ponnachi) in five directions. Within each transect six plots of $50 \mathrm{~m} \times 20 \mathrm{~m}$ were laid at an interval of $200 \mathrm{~m}$ to enumerate trees $(>10 \mathrm{~cm}$ diameter at breast height $[\mathrm{DBH}])$ and within this a $10 \mathrm{~m} \times 10 \mathrm{~m}$ plot was laid to sample understorey species $(<10 \mathrm{~cm}$ and $>3 \mathrm{~cm} \mathrm{DBH})$. A $1 \mathrm{~m} \times$ $1 \mathrm{~m}$ plot was laid within this to assess herb layers. Data on vegetation structure at BR Hills from an earlier study were used to compare across the three study sites (Murali et al. 1996). Besides the vegetation structure, several vegetation attributes such DBH, height, abundance, epiphyte load, and number of cut and broken stems were recorded in each transect along with attributes such as GPS location, altitude and distance from the settlement.

\section{Ecological costs}

As a measure of the ecological costs, we estimated four variables. At each site, the percentage of cut and broken stems of the total stems was computed for regions near to $(0-600 \mathrm{~m})$ and distant from $(600-1200 \mathrm{~m})$ the human settlements. Sites with greater percentage of cut and broken stems were assumed to bear a larger ecological cost than those with less damage, which was mainly attributable to the destructive means of harvest of NTFPs and to indirect pressures on the forest (such as for fuelwood collection).

As a measure of the effect of human disturbance, we calculated the frequency distribution of size class of stems of NTFP species and also Phyllanthus sp. $(<10$ and $>10 \mathrm{~cm}$ $\mathrm{DBH})$ for regions near to $(0-600 \mathrm{~m})$ and distant from
(600-1200 m) settlements. We also determined the percentage reduction in the regeneration at regions near to $(<600 \mathrm{~m})$ from settlements compared to more distant regions. The analysis was done for two sites, MM Hills (see above) and BR Hills (data obtained from Murali et al. 1996).

Among the various methods used for harvesting forest fruits, broadly two categories could be identified, namely those that are destructive to the trees and those not destructive. The former include practices such as cutting and breaking the branches, while in the latter fruits are picked or dislodged from the tree by shaking or beating the branches with sticks. Across the three sites, we determined the percentage of respondents that adopted ecologically friendly (non-destructive) methods for harvesting fruits of Phyllanthus sp., the predominant NTFP from the sites.

While harvesting fruits from trees, collectors could collect the entire harvest (to maximize returns to their initial costs of having climbed the tree or having spent time at the tree) or leave a proportion of fruit that could be used by the local wildlife and to favour regeneration; such prudent practice could be at the expense of the short-term gains of the collector (Prasad et al. 2001). We calculated the percentage of the respondents that adopted such prudent practices in harvesting of forest fruits at the three sites.

\section{RESULTS}

\section{Livelihood dependence}

The three sites differed markedly in the dependence on NTFPs. The community at BR Hills derived nearly 59\% of their total cash income from NTFPs, that in Nagarahole 24\% and that of MM Hills 16\% (Table 3). Within MM Hills, the dependence was significantly affected by both the location of settlements and the ethnicity of the people. At one of the settlements in MM Hills, Kombudikki, 40\% of the total income was obtained from NTFPs, while at another settlement, Ponnachi, it was only 6\%. At both these settlements, the tribal community (Soligas) derived a greater proportion of their total income from NTFPs than the non-tribal community (Lingayats; Table 3). Moreover, it is likely that the contracts mechanism that permits a trader to employ outside (non-local) harvesting labour contributes to a reduction in harvesting activity by the local population.

At all three sites, a range of NTFPs were extracted from the forest, including bamboo, forest fruits and other forest products. In BR Hills, for example, over $10.8 \%$ of total income was derived from three forest fruits (Phyllanthus emblica, Terminalia chebula, Acacia concinna) while that in MM Hills and Nagarahole it was $4.8 \%$ and $1 \%$, respectively (Table 3 ). Besides bamboo and fruits, forest products including honey, lichens, broomstick grass and herbal roots contributed nearly $45 \%$ and $25 \%$ of the total income at BR Hills and Nagarahole, respectively (Table 3). At MM Hills, in the Kombudikki settlement, the tribal community obtained about 34\% of their total income from bamboo; in comparison, the non-tribal 
Table 3 Per cent income (mean \pm standard deviation) from different sources in the three sites and two ethnic groups in two settlements, Kombudikki and Ponnachi, in MM Hills (marked as ${ }^{\#}$ ). The mean and standard deviations refer to the sample respondents interviewed at each site. The MM Hills data refer to the pooled estimate from the two settlements. Results of t-test assuming unequal variance; ${ }^{*} p=0.04$, ${ }^{* *} p=0.0333,{ }^{* * *} p=0.0001$.

\begin{tabular}{|c|c|c|c|c|c|c|c|}
\hline \multirow[t]{2}{*}{ Sources of income } & \multicolumn{2}{|c|}{ Kombudikki } & \multicolumn{2}{|c|}{ Ponnachi $^{\#}$} & \multirow[t]{2}{*}{ MM Hills } & \multirow[t]{2}{*}{ BR Hills } & \multirow[t]{2}{*}{ Nagarahole } \\
\hline & Tribals & Non-tribals & Tribals & Non-tribals & & & \\
\hline Agriculture & 03.12 & 03.65 & 09.33 & 18.66 & $09.60 \pm 18.23$ & $09.29 \pm 23.41$ & $12.24 \pm 25.42$ \\
\hline Live stock & 01.92 & 08.24 & 03.46 & 07.17 & $06.41 \pm 14.10$ & $01.80 \pm 05.71$ & $00.61 \pm 01.61$ \\
\hline Daily wage labour & 39.40 & 51.20 & 59.28 & 29.22 & $46.86 \pm 37.18$ & $23.37 \pm 43.93$ & $62.05 \pm 33.64$ \\
\hline Others & 00.49 & 11.01 & 15.50 & 44.82 & $21.21 \pm 33.47$ & $06.33 \pm 31.45$ & $01.42 \pm 05.03$ \\
\hline$\%$ income from non-NTFP & 44.93 & $74.10^{*}$ & 87.56 & $99.86^{* * *}$ & 84.09 & 40.79 & 76.31 \\
\hline Bamboo & 33.88 & 00.12 & 06.52 & 00.0 & $06.60 \pm 17.82$ & $02.92 \pm 18.12$ & $00.04 \pm 00.18$ \\
\hline Forest fruits & 15.80 & 08.28 & 05.56 & 00.14 & $04.79 \pm 09.14$ & $10.80 \pm 22.73$ & $01.00 \pm 03.56$ \\
\hline Forest products & 05.39 & 17.51 & 00.36 & 00.0 & $04.52 \pm 13.59$ & $45.49 \pm 71.53$ & $22.65 \pm 29.06$ \\
\hline$\%$ income from NTFP & 55.07 & $25.90^{* *}$ & 12.44 & $00.14^{* * *}$ & 15.91 & 59.21 & 23.69 \\
\hline
\end{tabular}

Table 4 Relation between wealth index $(\mathrm{x})$ and income from NTFPs (y). * Two sites at MM Hills. For details see text.

\begin{tabular}{lllll}
\hline \hline Sites & $n$ & \multicolumn{1}{l}{$\boldsymbol{y}=\boldsymbol{b} x+\boldsymbol{a}$} & \multicolumn{1}{l}{$\boldsymbol{R}^{2}$} & \multicolumn{1}{c}{$\boldsymbol{p}$} \\
\hline Kombudikki* & 36 & $-0.360 x+0.54$ & 0.075 & 0.106 \\
Ponnachi* $^{*}$ & 89 & $-0.052 x+0.08$ & 0.002 & 0.649 \\
BR Hills & 52 & $-0.206 x+0.39$ & 0.029 & 0.229 \\
Nagarahole & 28 & $0.273 x+0.04$ & 0.065 & 0.191 \\
\hline \hline
\end{tabular}

community obtained only $0.1 \%$ of their income from bamboo. Thus, it appears that the patterns of dependence on different NTFPs are likely to be fashioned by ethnic predispositions as well as by the availability and accessibility of the resources.

We calculated the major determinant of total household cash income for each of the sites. At BR Hills, daily wage labour $(p<0.03)$ and tree crops $(p<0.03)$ contributed significantly to total income. At Nagarahole, besides daily wage, agriculture $(p<0.001)$ and forest products $(p<0.001)$ were significant determinants of total income. In contrast, at MM Hills, forest fruits and forest products contributed weakly to total income. Per cent income from NTFPs was negatively correlated with per cent income from agriculture (BR Hills, $R^{2}=0.375$, $p<0.01$; MM Hills (at Ponnachi): $R^{2}=-0.009, p>0.05$; Nagarahole, $\left.R^{2}=0.049, p>0.05\right)$, indicating that at all sites, increasing access to land tenure and agriculture could relieve or reduce the dependence of people on NTFPs.

Within a given site (except in Nagarahole), the per cent dependence of households on NTFPs was found to decrease with increase in the wealth index of the households. In other words, it appears that at BR Hills and MM Hills, the poorer households seemed to depend more on income from NTFPs than did the richer households (Table 4).
As a measure of the distribution profile of income among households within a settlement, we developed Lorenz curves for the various settlements by respectively including and excluding the income from NTFPs in the total household income. Except for Ponnachi (tribals) and Nagarahole, the area between the Lorenz curve and the equality line decreased when NTFPs were included in the total household income, suggesting that income from NTFPs tend to reduce income inequalities among households. These patterns are reflected in the Gini coefficient (GC). For most settlements, the GC was smaller (indicating a more equal distribution) when NTFPs were included in the analysis. These results indicate that the income obtained from NTFPs helps to minimize the income disparities among the people and render the community economically more equitable (Table 5).

\section{Ecological knowledge of communities}

Among the three sites, the community at BR Hills appeared to be the most knowledgeable (Fig. 3). Thus a larger per cent of the respondents at BR Hills had information on issues such as the adverse effects of invasive species on regeneration, effect of fire on regeneration and productivity cycles of trees. For example, a greater proportion of respondents at BR Hills were knowledgeable of the effect of an epiphytic parasite on the productivity of the Phyllanthus trees $(G=21.30 ; d f=12 ; p=0.0000$; Fig. 4$)$. While $92 \%$ of the people in BR Hills knew that the epiphyte lowers the productivity, at MM Hills only 58\% of the people thought so. Besides the knowledge of specific plants that were extracted, people's insights into general ecosystem processes such as pollination, dispersal and effect of grazing on forest structure
Table 5 Gini coefficient (GC) values for the three sites with and without NTFP as a source of income. ${ }^{*}$ Two settlements at MM Hills. Tribals and non-tribals refer to the two ethnic groups over which the study was conducted.

\begin{tabular}{|c|c|c|c|c|c|c|}
\hline & \multicolumn{2}{|c|}{ Kombudikki* } & \multicolumn{2}{|c|}{ Ponnachi* } & \multirow{2}{*}{$\frac{\text { BR Hills }}{\text { Tribals }}$} & \multirow{2}{*}{$\begin{array}{l}\text { Nagarahole } \\
\text { Tribals }\end{array}$} \\
\hline & Tribals & Non-tribals & Tribals & Non-tribals & & \\
\hline Without NTFP & 0.28 & 0.74 & 0.33 & 0.37 & 0.76 & 0.34 \\
\hline With NTFP & 0.10 & 0.28 & 0.19 & 0.34 & 0.56 & 0.36 \\
\hline
\end{tabular}




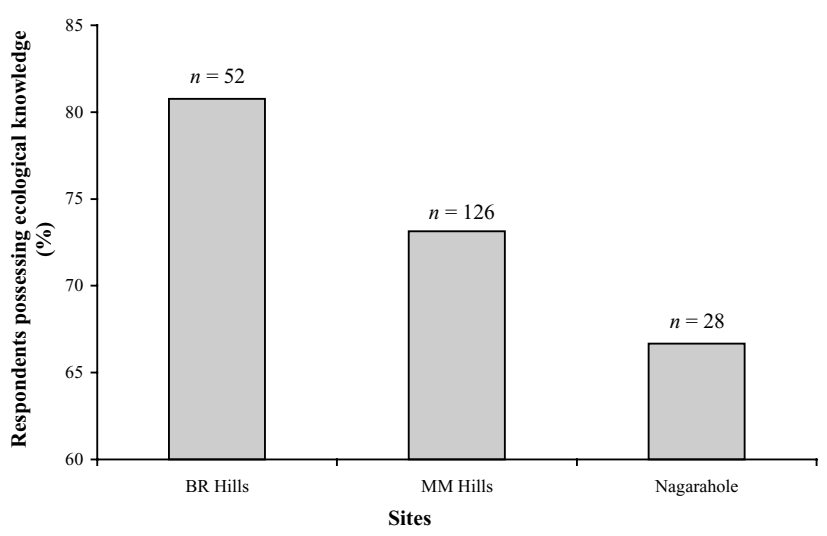

Figure 3 Per cent of respondents possessing knowledge on issues related to pollination, dispersal, seedling development, weeds, harvesting method and parasite attack at the three sites. $n=$ number of households interviewed.

were also sought. On average, the percentage of respondents knowledgeable about these issues was again higher for the community at BR Hills, followed by those at Nagarahole and MM Hills.

\section{Market channels and price spread at MM Hills and BR Hills}

The marketing channels for NTFPs in BR Hills and MM Hills differed strikingly. At BR Hills, tribal cooperatives involving the local collectors were responsible for the marketing of NTFPs. In MM Hills, NTFPs were harvested through private traders on short-term (two year) monopoly contracts awarded by the Karnataka Forest Department. This single difference seems to play an important role in determining the extraction pattern, return to the harvesters, marketing channels, price-spread and value addition to the raw products. The commodity flowchart for the forest products in BR Hills, where the cooperative itself undertook trading of the

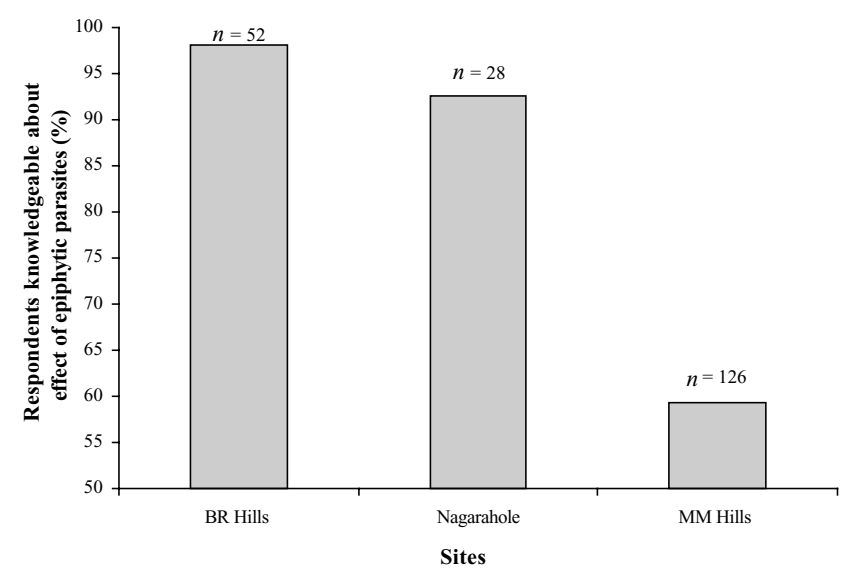

Figure 4 Per cent of respondents in the study sites knowledgeable about the effect of epiphytic parasites on the productivity of Phyllanthus sp.

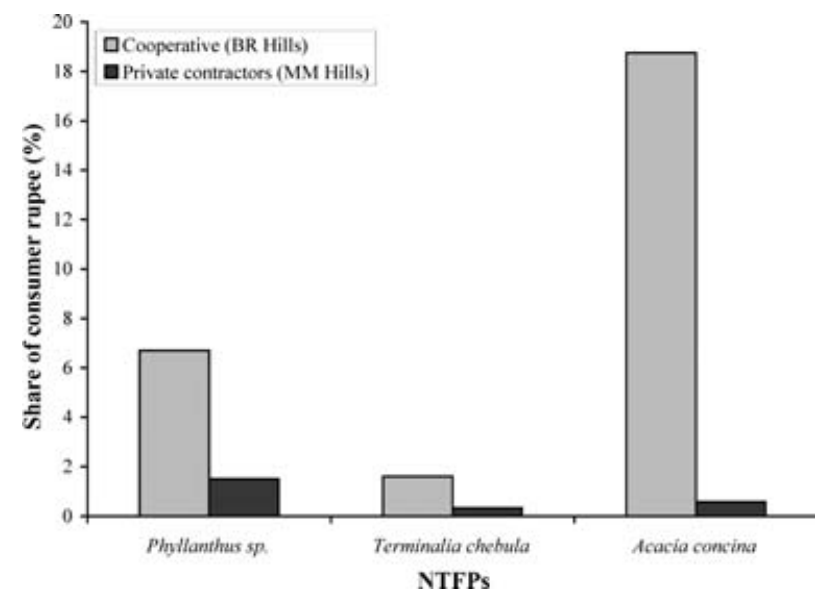

Figure 5 Per cent share of the consumer rupee to collectors at BR Hills and MM Hills.

commodity is shorter compared to that at MM Hills; in the latter a distinct agent is involved in marketing the commodity. The shorter channel at BR Hills compared to the longer channel at MM Hills may be more cost efficient.

However, the ultimate reach of products emerging from MM Hills was larger than that of those from BR Hills. The latter might be attributed mainly to the initiative undertaken by the private contractors and traders to search for more profitable markets and better returns to their resources and products. The contrasting patterns of marketing significantly affected the price-spread and the per cent share of the consumer rupee accruing to the collectors. The per cent share of the consumer rupee was significantly lower for all three forest fruits (Phyllanthus sp., Terminalia chebula and Acacia concinna; Fig. 5) at MM Hills compared with that at BR Hills. The harvesters of amla at BR Hills received $6.5 \%$ higher wages than those at MM Hills. Similarly for yet another NTFP, Acacia concinna, the harvesters at MM hills received a $12.5 \%$ lower share compared to those in BR Hills. The contractors' monopoly of NTFP collection and sales, and their level of 'business acumen' compared with the collectors are additional factors that would explain the reduced 'upstream' margins.

\section{DISCUSSION}

Our study reiterates the important contribution of NTFPs to the livelihoods of the forest dwelling communities in south India. In fact at BR Hills, the per cent of total income obtained from NTFPs has remained nearly unaltered $(\sim 55-59 \%)$ over the last decade (Hegde et al. 1996). However it is increasingly realized that such continued dependence of communities on forest products will be contingent upon minimizing the ecological costs that might be incurred. Understanding the features of forest use that contribute to ecological cost should help in formulating rational management strategies to reduce or avoid the costs thus securing the longterm livelihood gains. Our study on the three human 
settlements in south India has provided a rich canvas of contrasts to examine some of the direct and indirect costs that dependence on forest can have. Using these contrasts as the template, we provide below the first order evaluation of the predictions and associations relating to the ecological costs in these forest communities and discuss approaches that could lower the cost and hence ensure livelihoods.

The results of our study show that ecological knowledge of people scales positively with the extent of their dependence on the forest. Thus the community at BR Hills that depend on forest resources to a larger extent exhibited a greater awareness of the ecological issues than did communities at Nagarahole and MM Hills. This association might be a consequence of the historical linkages that the communities might have had with the resources they have to depend upon. In BR Hills, the higher awareness of the community might also have come through acquiring information from non-governmental (NGOs) and community-based organizations (CBOs) actively promoting ecologically friendly methods of forest use in the region in the recent past.

We examined two parameters of the community as a possible measure of the ecological cost, namely the percentage of collectors at each site that (1) adopted ecologically friendly harvesting methods and (2) adopted a certain degree of resource prudence while harvesting fruits.

Our results showed that with increasing dependence on NTFPs, the percentage of the collectors that adopted ecologically friendly harvesting methods and harvesting prudence increased. A greater proportion of the people at BR Hills and Nagarahole (with higher per cent dependence on NTFPs) resorted to beating branches to dislodge fruits from trees (Table 6). These collectors seem to have a clear knowledge that other methods of harvesting (such as cutting) could be destructive to the long-term productivity of the trees. On the other hand, at MM Hills a smaller proportion of the collectors resorted to beating branches, while others adopted destructive methods of harvesting fruits from trees. Similarly, the people at BR Hills and Nagarahole resorted to a less intense harvest, choosing to leave behind more fruits for tree recruitment and consumption by wildlife compared to the people in MM Hills. Thus, it appears that communities with a greater degree of ecological knowledge might be more prudent in the use of forest resources than those not well

Table 6 Per cent dependence, per cent respondents knowledgeable about non-destructive harvest method and practising prudent harvesting. ${ }^{1}$ This included respondents who resort to beating branches to dislodge fruits from Phyllanthus sp., the predominant NTFP collected from the sites. ${ }^{2}$ This included respondents who left behind a certain proportion of fruits on trees of Phyllanthus sp.

\begin{tabular}{llll}
\hline \hline Attributes & BR Hills & Nagarahole & MM Hills \\
\hline Dependence & 51.21 & 23.69 & 15.91 \\
$\begin{array}{c}\text { Harvest method } \\
\quad \text { (non-destructive) }\end{array}$ & 44.23 & 85.19 & 24.01 \\
$\begin{array}{c}\text { Intensity (prudent } \\
\text { harvesting) }\end{array}$ & 63.46 & 77.78 & 5.33 \\
\hline \hline
\end{tabular}

informed. This finding might have important implications for the rationale management of NTFP resources.

The observed differences in the methods and intensity of harvesting could also be viewed as a consequence of the different marketing systems and institutional frameworks in the study sites. At MM Hills, the two-year contracts for harvest of the forest produce are awarded on the basis of a competitive bid and hence continuity and long-term approaches to harvesting cannot be assumed. This is likely to result in market failure, because there is an element of uncertainty to the private contractor of collection rights in the long run which is likely to undermine incentives to conserve the NTFP by the private contractor. This may lead to harvesting of an exploitative nature, wherein the contractor is forced to maximize his short-term gains.

Under a private market structure, poor collectors, either local or not, could be forced to resort to excessive extraction in order to earn their living because their returns per unit of collection are very low. Another feature of the marketing through the private contractors is that they are free to employ collectors, either from within the forest settlement or outside. This is also likely to influence the ecological responsibility of collectors' harvesting practices. These two features together could significantly influence the ecological cost of extraction of forest products. In apparent support of this argument is the fact that people at MM Hills were on average less knowledgeable about the ecology of forest trees that were the people at BR Hills or Nagarahole. Because of the interest in maximizing short-term gains, a larger percentage of the collectors at MM Hills resort to (1) very intense collection per tree (as much as the contractor, the collector is also maximizing his or her return) and (2) destructive harvesting of the trees. Private markets may not only be exploitative of the collectors (by way of providing a small proportion of the consumer rupee to the collector), and inequitable concerning the balance of market power, but also exploitative of the natural habitat.

The result could also be viewed in the light of the theory of evolution of prudence in communities. To be prudent incurs a short-term cost and, unless the gains are justified in the long-term, it would not pay to be prudent. Thus, in MM Hills, where individual collectors and the contractor may try to maximize the short-term gains, prudence could be weakly, if at all, selected compared with BR Hills where the existing market organization and institutions favour maximizing longterm gains.

\section{Measure of ecological cost}

But are the differences in ecological knowledge among the communities actually manifested in a better health status of the trees at sites such as BR Hills compared with that at MM Hills? We used two indicators that could be comparable across the sites to address this question, namely the per cent cut and broken stems, as a measure of the extent of disturbance to the forest, and regeneration status of certain focal species harvested by the communities. 
Table 7 Proportion, mean and standard deviation of cut and broken stems at regions near to and distant from settlements in the study sites. *From Murali et al. (1996).

\begin{tabular}{llll}
\hline \hline Area & $\begin{array}{l}\text { \% Cut and } \\
\text { broken stems }\end{array}$ & $\begin{array}{l}\text { \% Cut and broken } \\
\text { stems }<600 \mathrm{~m} \\
\text { from settlements }\end{array}$ & $\begin{array}{l}\text { \% Cut and broken } \\
\text { stems } 600-1200 \mathrm{~m}\end{array}$ \\
from settlements
\end{tabular}

At both sites, the percentage of cut and broken stems and the size class of stems were estimated near to $(<600 \mathrm{~m})$ and distant from $(600-1200 \mathrm{~m})$ human settlements. The per cent cut and broken stems was less in Nagarahole and BR Hills both near to and distant from settlements compared with that at MM Hills (Table 7). At both sites, the regeneration of focal NTFP species such as Phyllanthus sp., the predominant NTFP, was affected more in nearby than distant regions (BR Hills: $\chi^{2}=32.38, p=1.27 \times 10^{-8}$ and MM Hills: $\chi^{2}=19.21, p=1.17 \times 10^{-5}$; Fig. 6); however, at BR Hills the per cent reduction of stems $(<10 \mathrm{~cm}$ DBH) in near over that in distant regions was substantially less than that at MM Hills $\left(\chi^{2}=22.15, p=2.52 \times 10^{-6}\right.$; Fig. 7). Thus, though at both sites there was a decrease in regeneration at regions near to the settlements (perhaps

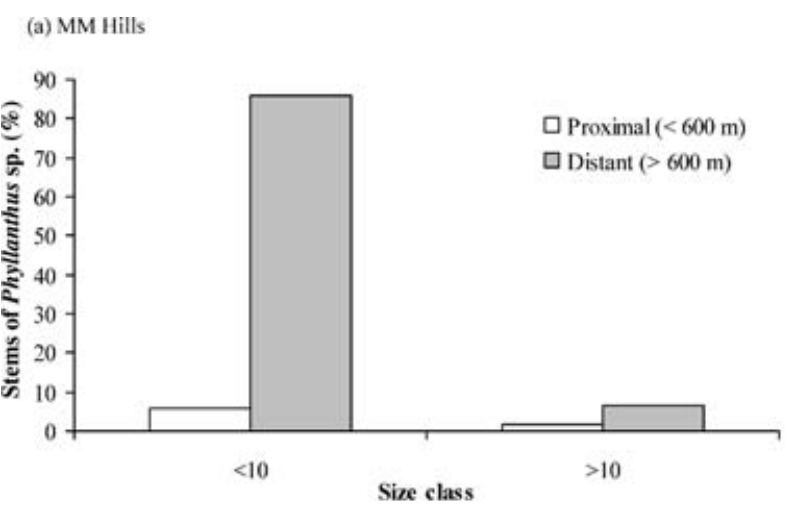

(b) BR Hills

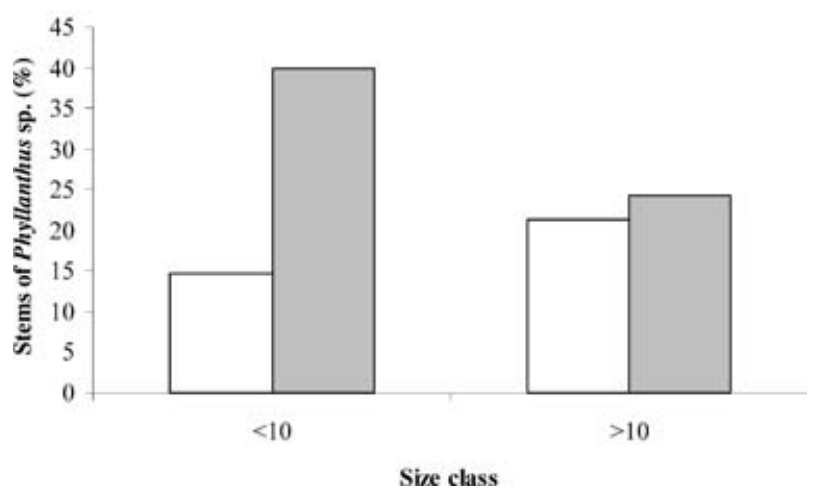

Figure 6 Per cent of stems of Phyllanthus sp. $(<10 \mathrm{~cm}$ and $>10 \mathrm{~cm}$ $\mathrm{DBH})$ at regions proximal $(<600 \mathrm{~m})$ and distant $(600-1200 \mathrm{~m})$ from settlements at (a) MM Hills and (b) BR Hills.

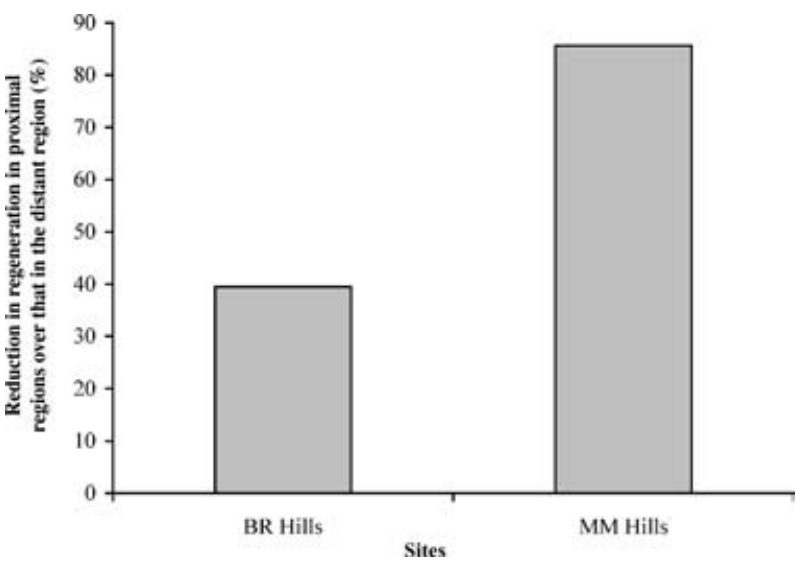

Figure 7 Per cent reduction in regeneration $(<10 \mathrm{~cm} \mathrm{DBH})$ of Phyllanthus sp. at regions near to $(<600 \mathrm{~m}$ from $)$ settlements compared to more distant regions at BR Hills and MM Hills.

because of an increased level of harvesting and other humanmediated disturbances), in BR Hills the effects seem to be subdued.

Despite high dependence, communities could have evolved strategies for reducing the ecological cost, provided of course they are knowledgeable of the ecosystem in which they operate. These communities (that have a high dependence) are by nature traditionally wedded to the resources and therefore might have had the time to evolve the necessary wherewithal to maintain the productivity of the specific resources. In contrast, communities with low dependence and associated private marketing systems are characteristic of opportunistic exploitation, interested mainly in maximizing the short-term gains. Our studies provide important pointers to the management of the NTFP resources, considering the level of dependence of communities on the NTFP. These results also hold important implications for defining optimum marketing systems and institutions to optimize the ecological cost of collection. Private contractor marketing could be made conditional upon regulations pertaining to ecologically friendly methods of harvesting, coupled with close monitoring of the process.

While our study has demonstrated the possible role of the extent of dependence, indigenous knowledge and markets in influencing the ecological cost, there are several additional factors that merit mention. It is often not easy to tease these explanations apart and it is likely that in reality a host of factors overlay each other in determining the costs. For example, the reduced ecological cost observed at BR Hills and Nagarahole could also arise because of the overriding legislation that protects these forests compared to that at MM Hills. Similarly agricultural land tenure and property rights, and other livelihood opportunities could also influence the ecological costs by modulating the extent to which people are dependent upon NTFPs. Lack of land tenure at BR Hills compared to that at MM Hills could drive people to have a greater share of income from NTFP collection than settled 


\begin{tabular}{|l|l|l|}
\hline \multirow{2}{*}{ Livelihoods Gains } & \multicolumn{2}{|c}{ Ecological Costs } \\
\cline { 2 - 3 } & \multicolumn{1}{|c|}{ Win } & \multicolumn{1}{|c}{ Lose } \\
\hline Win & $\begin{array}{l}\text { Win-Win } \\
\text { (Desired) }\end{array}$ & Win-Lose \\
\hline \multirow{2}{*}{ Lose } & $\begin{array}{l}\text { Lose-Win } \\
\text { (Protected area) }\end{array}$ & $\begin{array}{l}\text { Lose-Lose } \\
\text { (Wastelands) }\end{array}$ \\
\hline
\end{tabular}

Figure $82 \times 2$ matrix of livelihood gains and ecological costs. The bold arrows indicate the trajectory of change that is desired. The dotted arrow indicates the likely trajectory if disparities between gains and costs widen.

agriculture. Unfortunately, the lack of suitable contrasts in sociological settings constrain sieving the observed causality of associations.

\section{Enhancing livelihoods, optimizing ecological costs}

Under most current extractive practices, gains in livelihoods attract an ecological cost (win-lose situations; Fig. 8). Situations of lose-win (with no apparent livelihood gains and thus no ecological cost) are perhaps typical only of nationally protected areas, from where extraction of NTFPs is prohibited. On the other hand, the lose-lose outcome is probably typical of wastelands where either because of past exploitative extraction events or natural processes, livelihood gains are absent, and hence there are no overt ecological costs. The most ideal outcome is the win-win, where there is a certain equilibrium between the livelihood gains and ecological costs. Within the available possibilities, it appears that unless efforts are taken to reduce the skew between the gains and the costs (in the win-lose cells), sooner or later the elements in the cell will graduate to a lose-lose mode (because of overextraction). Reduction of skew between the gains and costs could be the first step in redirecting the trajectories of change to a win-win mode.

While conceptually the $2 \times 2$ matrix of win-lose offers a rich canvas to navigate the options, in practice reaching a win-win situation is uncommon. In the absence of green tree felling in countries such as India, NTFPs have come to stay as the major extractable produce of the forest. Under these conditions, managing NTFP extraction is a key to both conserving the forest at large as well as in securing the continuous needs of the rural poor. While there has been a general realization that dependence of forest fringe communities on forest resources could entail a certain ecological cost, there have not been many efforts to explicitly address the costs. Our study has examined the consequences of livelihood dependence by people on the ecological consequences with the ultimate goal of exploring the possibilities of bridging the gap between the livelihood gains and the ecological costs. Within the short-term of the study, we have shown that the extent of dependence on NTFPs, indigenous ecological knowledge and market organization and institutions could have an important bearing on the ecological cost and that addressing these factors could form an approach towards mitigating the loss. However, this does not necessarily preclude or undermine the possible role that other factors (land tenure, alternative income opportunities, etc.) could have in minimizing the ecological cost. Thus, the approaches to reducing the costs could be several and perhaps need to be carefully prioritized, based on locale-specific features.

We argue that adaptive management that enhances the ecological knowledge bases of harvesting communities and that regulates market structure to favour long- rather than short-term gains could narrow the disparities between livelihood gains and ecological costs and thus lead to a greater livelihood security in poor communities. Among the potential interventions and possible recommendations, our study indicates that while maintaining or enhancing livelihoods from forest, focus should also be laid on reducing the ecological cost of dependence. These interventions could include an array of features, such as adoption of ecologically friendly methods of harvesting, spatial and temporal monitoring of harvesting by collectors, formulation of property rights that are aligned with incentives for long-term management, and harvesting regimes that are not exploitative on the collectors and the ecosystem. Several major policy issues that could help lower the ecological cost include the implementation of the concept of NTFP working plans, similar to the timber working plans, and semi-domestication of, at least, the most important and threatened plant resources.

\section{ACKNOWLEDGEMENTS}

This publication is an output from a research project (R7349, Forestry Research Programme) funded by the United Kingdom Department for International Development (DFID) for the benefit of developing countries. The views expressed are not necessarily those of DFID. A McArthur Foundation grant to K.S. Bawa, R. Uma Shaanker and K.N. Ganeshaiah supported part of the work reported from BR Hills site. We are grateful to the Karnataka Forest Department for permission to work in MM Hills and Nagarahole forest. We are thankful to our field assistants and driver, Mr Veerabhadra, Mr Mahadesha, Mr Neelaiah and Mr Laxmikantha, for help rendered during the fieldwork.

\section{References}

Bawa, K., Rose, J., Ganeshaiah, K.N., Barve, N., Kiran, M.C. \& Uma Shaanker, R. (2002) Assessing biodiversity from space: an example from the Western Ghats, India. Conservation Ecology 6: 7 [www document]. URL http://www.consecol.org/vol6/iss2/ art7

Chaluvaraju, Singh, D.B., Rao, M.N., Ravikanth, G., Ganeshaiah, K.N. \& Uma Shaanker, R. (2001) Conservation of bamboo genetic resources in Western Ghats: status, threats and strategies. In: Forest Genetic Resources: Status, Threats and Conservation Strategies, ed. R. Uma Shaanker, K.N. Ganeshaiah \& K.S. Bawa, pp. 97-113. New Delhi, India: Oxford-IBH Publications. 
Ganeshaiah, K.N. \& Uma Shaanker, R. (1998) BRT Sanctuary: a biogeographic bridge of the Deccan Plateau. In: Biligiri Rangaswamy Temple Wildlife Sanctuary: Natural History, Biodiversity and Conservation, ed. K.N. Ganeshaiah \& R. Uma Shaanker, pp. 4-6. Bangalore, India: ATREE and VGKK.

Ganeshaiah, K.N., Uma Shaanker, R., Murali, K.S., Uma Shanker \& Bawa, K.S. (1998) Extraction of non-timber forest products in the forests of Biligiri Rangan Hills. 5. Influence of dispersal mode on species response to anthropogenic pressures. Economic Botany 52: 316-319.

Ghazoul, J. (2001) Direct and indirect effect of human disturbance on the reproductive ecology of tropical forest trees. In: Tropical Ecosystems: Structure, Diversity and Human Welfare, ed. K.N. Ganeshaiah, R. Uma Shaanker \& K.S. Bawa, pp. 97-100. New Delhi, India. Oxford-IBH Publications.

Hall, P. \& Bawa, K.S. (1993) The economic value and sustainable harvest of plants and animals from the tropical forest: assumptions, hypotheses, and methods. Economic Botany 47: 215 219.

Hegde, R., Suryaprakash, S., Achoth, L. \& Bawa, K.S. (1996) Extraction of NTFPs in the forests of BR Hills 1. Contribution to rural income. Economic Botany 50: 243-250.

Kakwani, N.C. \& Podder, N. (1976). Efficient estimation of Lorenz curve and association inequality measures form grouped observation. Econometrics 44: 138-148.

Lorenz, M.O. (1905) Methods of measuring concentration of wealth. Fournal of the American Statistical Association 9: 209-219.

Murali, K.S., Uma Shankar, Uma Shaanker, R., Ganeshaiah, K.N. \& Bawa, K.S. (1996) Extraction of NTFPs in the forests of BR Hills. 2. Impact of NTFPs extraction on regeneration, population structure and species composition. Economic Botany 50: 251-269.

National Centre for Human Settlements and Environment (1987) Documentation of Forest and Rights. Volume 1. New Delhi, India: National Centre for Human Settlements and Environment.

Nepstad, D.C., Brown, I.F., Luz, L., Alechandra, A. \& Vlana, V. (1992) Biotic impoverishment of Amazonian forests by tappers, loggers and cattle ranchers. In: Non-Timber Products from Tropical Forests: Evaluation of Conservation and Development Strategy, ed. D.C. Nepstad \& S. Schwartzman, pp. 1-14. Advances in Economic Botany Volume 9. Bronx, NY, USA: The New York Botanical Garden.

North, D.C. (1990) Institutions, Institutional Change and Economic Performance. Cambridge, UK: Cambridge University Press.

Ostrom, E. (1990) Governing the Commons: The Evolution of Institutions for Collective Action. Cambridge, UK: Cambridge University Press.

Padmini, S., Rao, M.N., Ganeshaiah, K.N. \& Uma Shaanker, R. (2001) Genetic diversity of Phyllanthus emblica in tropical forests of South India: impact of anthropogenic pressures. Fournal of Tropical Forest Science 13: 297-310.

Peres, C.A., Baider, C., Zuidema, P. A., Wadt, L.H.O., Kainer, K.A., Gomes-Silva, D.A.P., Salomão, R.P., Simões, L.L., Franciosi, E.R.N., Valverde, F.C., Gribel, R., Shepard Jr, G.H., Kanashiro, M., Coventry, P., Yu, D.W., Watkinson, A.R. \& Freckleton, R.P. (2003) Demographic threats to the sustainability of Brazil nut exploitation. Science 302: 2112-2114.

Poole, N.D. \& Bhupal, D.S. (2003) Interim report on improved vegetable marketing in Delhi. 'Enhancing food chain integrity: quality assurance mechanisms for air pollution impacts on fruit and vegetable systems'. Unpublished report, DFID Crop PostHarvest Programme Project R7530. Imperial College London, Wye, Kent.

Poole, N.D. \& Sen, C. (2003) Interim report on consumer willingness to pay for quality-assured vegetables in Varanasi, India. 'Enhancing food chain integrity: quality assurance mechanisms for air pollution impacts on fruit and vegetable systems'. Unpublished report, DFID Crop Post-Harvest Programme Project R7530. Imperial College London, Wye, Kent.

Prasad, S., Chellam, R. \& Krishnaswamy, J. (2001). Fruit removal patterns and dispersal of Emblica officinalis (Euphorbiaceae) at Rajaji National Park, India. In: Tropical Ecosystems: Structure, Diversity and Human Welfare, ed. K.N. Ganeshaiah, R. Uma Shaanker \& K.S. Bawa, pp. 513-516. New Delhi, India: OxfordIBH Publications.

Sinha, A. \& Bawa, K.S. (2001). Impacts of anthropogenic pressures on population dynamics, demography, and sustainable use of forest species in the Western Ghats, India. In: Tropical Ecosystems: Structure, Diversity and Human Welfare, ed. K.N. Ganeshaiah, R. Uma Shaanker \& K.S. Bawa, pp. 101-103. New Delhi, India: Oxford-IBH Publications.

Sokal, R.R. \& Rohlf, F.J. (1981) Biometry. New York, USA: W.H. Freeman and Company.

Tewari, D.N. (1993) Non-timber forest produce in poverty alleviation. Indian Forester Dec: 959-968.

Uma Shaanker, R., Ganeshaiah, K.N. \& Rao, M.N. (2001) Genetic diversity of medicinal plant species in deciduous forest of South India: impact of harvesting and other anthropogenic pressures. Journal of Plant Biology 28: 91-97.

Uma Shaanker, R., Ganeshaiah, K.N., Meera, C. \& Anuradha, H.R. (2000) Bamboo bazaar. Deccan Herald, Spectrum 7 April 2000.

Ved, D.K., Prathima, C.L., Mortan, N. \& Darshan Shankar (2001) Conservation of India's medicinal plant diversity through a novel approach of establishing a network of in situ gene banks. In: Forest Genetic Resources: Status, Threats and Conservation Strategies, ed. R. Uma Shaanker, K.N. Ganeshaiah \& K.S. Bawa, pp. 183-195. New Delhi, India: Oxford and IBH Publications. 